УДК 663.61

(C) 2012

Степова О. В., кандидат технічних наук,

Булавенко Р. В., кандидат сільськогосподарських наук, Рома В. В., стариий викладач

Полтавський національний технічний університет імені Юрія Кондратюка

\title{
АНАЛІЗ СТАНУ ПОВЕРХЕВИХ ВОД ПОЛТАВСЬКОЇ ОБЛАСТІ В КОНТРОЛЬНИХ СТВОРАХ
}

\section{Рецензент - доктор технічних наук, професор В. О. Бондар}

\begin{abstract}
Виконана екологічна оцінка стану річкових вод Полтавської області в районах розташування очисних споруд стічних вод промислових підприємств, господарсько-побутових стоків. Це дало змогу оцінити ситуацію, щзо склалася в досліджуваних водних об'єктах, $і$ класифікувати їх за ступенем придатності для основних видів водоспоживання. Очінка якості поверхневих вод здійснювалася на основі аналізу інформації стосовно величин гідрохімічних показників у порівнянні з відповідними значеннями їх гранично допустимих кониентрацій (ГДК).
\end{abstract}

Ключові слова: поверхневі води, контрольні створи, гідрохімічні показники, індекс забруднення води, екологічна ситуація.

Постановка проблеми. Погіршення екологічної ситуації річкових систем у Полтавській області внаслідок нераціонального використання водних ресурсів, значного техногенного впливу $\epsilon$ вкрай відчутною проблемою і несе приховану небезпеку для нинішнього й майбутніх поколінь. Визначення якості поверхневих вод грунтується на основі екологічної класифікації, що включає набір гідрофізичних, гідрохімічних, гідробіологічних та інших показників, які відображають особливості складових водних екосистем. Екологічна класифікація на основі інтегрального показника забруднення $є$ критерієм екологічної оцінки якості поверхневих вод, а остання - складовою частиною нормативної бази для комплексної характеристики стану навколишнього природного середовища й основою для оцінки впливу людської діяльності на довкілля. Виконання екологічної оцінки проводилося за допомогою інтегрального показника забруднення води.

Екологічні ризики від господарської діяльності, що проводилися і проводяться в Полтавській області, зумовлюють необхідність застосування комплексного підходу для вивчення довгострокових тенденцій і закономірностей зміни якісних показників поверхневих вод.

Аналіз сучасного екологічного стану водних джерел Полтавщини свідчить, що негативні процеси на річках, водосховищах і ставках тривають. Більшість річок і водотоків забруднені хімічними речовинами, які потрапили у водойми внаслідок скиду стічних вод промислових підприємств і втратили своє природне значення. Вони не мають дренуючої спроможності, в результаті чого заплавні землі заболочені й підтоплені і не використовуються в сільському господарстві. Проблема якісного й кількісного виснаження водних ресурсів із кожним роком стає все гострішою. Стан водної екосистеми Полтавської області в межах розташування очисних споруд відображає зростання техногенного навантаження, що обумовлює процес іiї деградації. Для покращання стану поверхневих водоймищ необхідно виділити приорітетні напрями екологічної діяльності. На сьогодні актуальним залишається питання щодо аналізу стану поверхневих водойм Полтавської області в контрольних створах i, відповідно, оцінювання роботи очисних споруд, які здійснюють скиди в поверхневі водойми.

Аналіз основних досліджень і публікацій, у яких започатковано розв'язання проблеми. Оцінити якісно й кількісно стан поверхневих вод, що знаходяться під впливом людської діяльності, досить складне завдання, оскільки залежить від багатьох факторів [2-4]. Визначення одночасно всіх показників не завжди $є$ необхідним та економічно доцільним. Практично (залежно від мети досліджень) оцінка якості поверхневих вод грунтується на обраних репрезентативних показниках, величини яких мають визначатися за уніфікованими методами аналізу якості компонентів довкілля [1].

Реальна оцінка екологічної обстановки, а також процесів, що відбуваються у поверхневих водах, неможливі без застосування максимально достовірних критеріїв, тобто якісних або кількісних ознак, взятих за основу класифікації стану поверхневих вод, якими можуть бути індекси забрудненості води (IЗВ). 
Метою досліджень $є$ екологічна оцінка стану поверхневих вод у контрольних створах у межах Полтавської області.

Об'єкт дослідження - контрольні створи поверхневих вод Полтавської області.

Матеріали досліджень. Аналіз стану забруднення поверхневих вод у контрольних створах виконано на основі даних спостережень за вмістом гідрохімічних показників, наданих Полтавським регіональним управлінням водних ресурсів.

Результати досліджень. Основними джерелами водних ресурсів області є річки Сула, Псел, Ворскла, Оріль та їх притоки, а також Кременчуцьке й Дніпродзержинське водосховища на річці Дніпро. Основними водокористувачамизабруднювачами водних об'єктів в області, що здійснюють скидання забруднених стоків, $\epsilon$ Полтавський ГЗК, Рижівський гранкар'єр (Гадяцький район), Кременчуцьке кар'єроуправління «Кварц», підприємства Укрзалізниці (станції Гребінка, м. Полтава), комунальні господарства, підприємства харчової промисловості та ін. Через не завершення робіт із реконструкції та капітального ремонту очисних споруд має місце скид недостатньо очищених стічних вод у поверхневі водні об'єкти області. 3 метою контролю й аналізу стану поверхневих водойм у місцях розміщення очисних споруд проводиться моніторинг та аналіз стану забрудненості водойм за групами показників.

Серед методів оцінки якості поверхневих вод виділяють: фізико-хімічні (засновані на індивідуальних і комплексних показниках), біологічні й комбіновані методи [4]. Для оцінки стану поверхневих вод Полтавської області обраний фізико-хімічний метод, оскільки він якнайточніше оцінює забруднення води конкретними забруднювачами, враховує сумісний вплив забруднюючих речовин, дає можливість класифікації якості води і характеристики середовища існування водних організмів. За результатами аналізу стану водоймищ розраховано індекси забрудненості води (ІЗВ) згідно з [3].

Аналіз стану якості поверхневих вод у місцях розташування каналізаційних очисних споруд проводився у контрольних створах двадцяти річок Полтавської області, а також у ставку дендропарку.

Проведено оцінку якості поверхневих вод у районах розміщення очисних споруд за період 2005-2010 років за наступними показниками: $\mathrm{pH}$, розчиненим киснем, БСК 5 i комплексним показником IЗВ (включаючи БСК нітрит-іони, хлорид-іони, нафтопродукти і фосфати). Обробка значного об'єму даних за тривалий час дає можливість визначити тенденцію в динаміці розрахункових показників.

Проведена екологічна оцінка якості річкових вод області в районі розташування очисних споруд дала змогу оцінити ситуацію, що склалася в досліджуваних водних об'єктах, і класифікувати ï за ступенем придатності для основних видів водоспоживання.

Протягом досліджуваного періоду загальний рівень забруднення поверхневих водойм у місцях розміщення очисних споруд за середніми значеннями індексу забруднення постійний і коливається в межах від «забруднені» (IV клас якості води) до «брудні» (V клас якості води) (рис. 1). 3 усіх контрольованих у 2010 році об'єктів області (20) переважна частина оцінюється як «помірно забруднена» та «забруднена». Головні інгредієнти, що обумовлюють низькі оцінки ділянок вод, - амоній-іони, нітрити, марганець, фосфати, розчинений кисень.

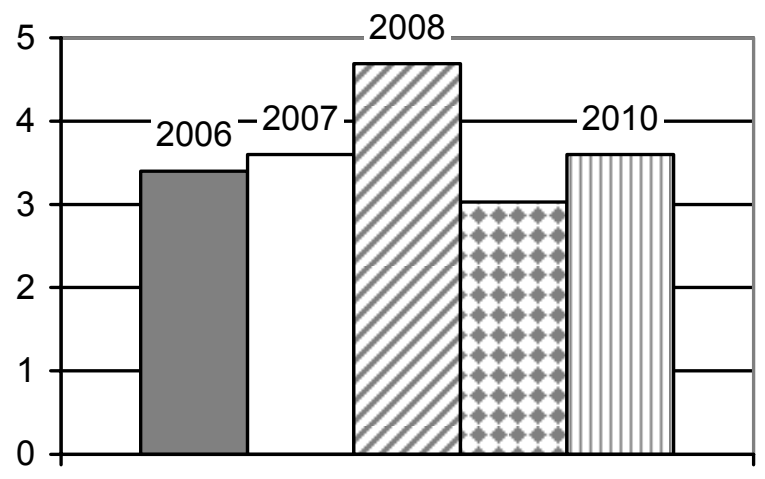

\section{Рис. 1. Динаміка зміни якості поверхневих водойм (за індексом забруднення води) в контрольних створах Полтавськоӥ області за роками}

У 2010 році за індексом забруднення якість води в контрольних створах Дніпра, Сули, Псла, Ворскли в цілому відноситься до III і IV класів, тобто коливається від «помірно забрудненої» до «брудної». Якість річкових вод Полтавщини в контрольних створах у середньому за індексом забруднення вважається «забрудненою» (IV клас) (рис. 2). Особливо нестабільний стан відносно забруднень склався в контрольних створах річок Крива Руда (очисні споруди Кременчуцької кондитерської фабрики та очисні споруди ЗАТ «Джей Ті Інтернешнл Україна»), p. Суха Лохвиця (очисні споруди Лохвицької дільниці Миргородського ВУВКГ), Коломак (очисні споруди ВАТ «Тепловозоремонтний завод»). 


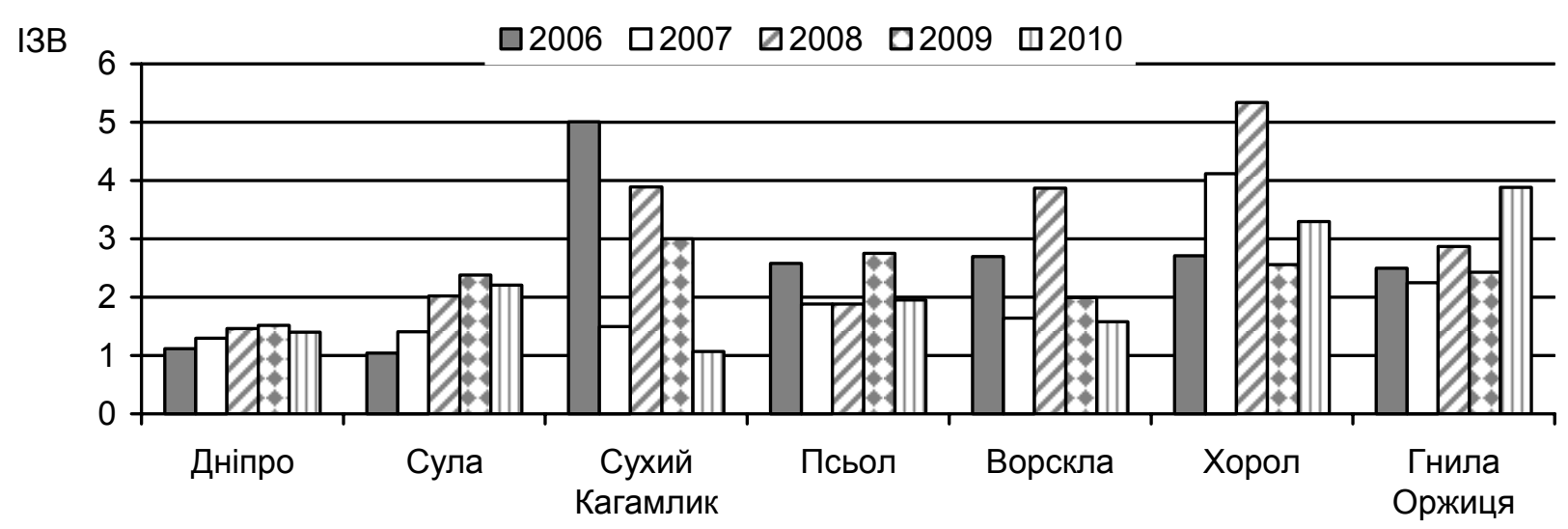

Рис. 2. Динаміка зміни якості деяких поверхневих вод у контрольних створах Полтавськоӥ області

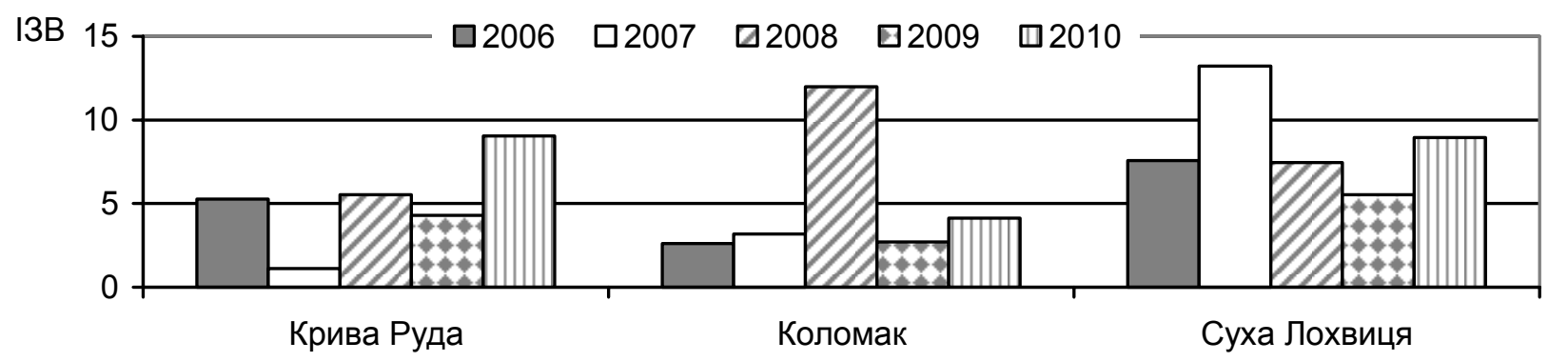

\section{Рис. 3. Динаміка зміни інтегрального показника забруднення (ІЗВ) у контрольних створах поверхневих водойм Полтавської області за роками}

Протягом досліджуваного періоду у зазначених контрольних створах значення індексу забруднення коливалося в межах 4,3-9,04 (р. Крива Руда), 2,6-4,14 (р. Коломак), 5,52-8,94 (р. Суха Лохвиця) (рис. 3). Станом на 2010 р. найбільш забрудненими контрольними створами є створи річок Крива Руда («дуже брудна», VI клас), Коломак («брудна», V клас), Суха Лохвиця («дуже брудна», VI клас).

За результатами екологічної оцінки, особливої уваги потребують окремі ділянки контрольних створів річок і Полтавських водосховищ, які визначені за ІЗВ як «брудні» й «дуже брудні».

Основними причинами погіршення якості води в контрольних створах річок Крива Руда, Суха Лохвиця, Коломак $є$ недостатня ефективність роботи наявних очисних споруд, незадовільний стан каналізаційних мереж, насосних станцій та споруд зливової каналізації. Зокрема, незадовільно працюють ті централізовані біологічні очисні споруди, де значна частка води припадає на промислові стічні води, які надходять на каналізаційні очисні споруди без попереднього очищення на локальних очисних спорудах підприємств. Відсутні або мають незадовільний стан каналізаційні мережі та очисні споруди у містах
Гадяч, Миргород, Пирятин, Глобине, Гребінка, Зіньків, Лохвиця, Козельщина, Градизьк, Котельва, Чутове, Опішня, Семенівка, смт. В. Багачка, смт. Чорнухи, що вносить «певний вклад» у стан якості поверхневих водойм Полтавської області в цілому і в контрольних створах зокрема.

Значну частку у забруднення поверхневих джерел області вносить змив 3 урбанізованих територій. Зі зливовими стічними водами до водних об'єктів надходять завислі речовини, органічні забруднювачі, нафтопродукти, азот, фосфорні та інші речовини.

Результати екологічної оцінки дали змогу виділити найбільш проблемні річкові зони й розробляти відповідні водоохоронні заходи. У зв'язку з нестабільним загальним станом поверхневих водойм, зокрема контрольних створів річкових зон, доцільно розробляти й впроваджувати заходи щодо захисту та відновлення малих річок Полтавської області для покращання екологічного стану поверхневих водойм області в цілому.

Одним із таких заходів $є$ підвищення рівня вимог до очищення стоків на очисних спорудах ЗАТ «Кременчуцької кондитерської фабрики», ЗАТ «Джей Ті Інтернешнл Україна», ВАТ «Теп- 
ловозоремонтного заводу» та проведення спеціального контролю в місцях їх скиду у відповідних створах.

Висновки. Аналізуючи дані проведеної оцінки, можна дійти висновку, що спостерігається сумна статистика збільшення кількості забруднених ділянок водойм і зменшення чистих. Причина такої тенденції обумовлена стічними водами промислових підприємств, господарськопобутовими стоками, незадовільною роботою

\section{БІБЛІОГРАФІЯ}

1. КНД 211.1.1.106-2003 «Організація та здійснення спостережень за забрудненням поверхневих вод». $-154 \mathrm{c.}$

2. Правила охорони внутрішніх морських вод $\mathrm{i}$ територіального моря України від забруднення та засмічення. Постанова Кабінету Міністрів України. - 2002 р., № 431. обладнання на очисних спорудах. Без прийняття практичних заходів із розчищення малих річок, модернізації існуючих та будівництва нових очисних споруд із реалізацією сучасних технологій видалення органічних забруднень і біогенних з'єднань азоту та фосфору неможливо вирішити проблему охорони водних об'єктів зменшення їх забруднення та покращання екологічного стану.

3. Сніжко C. I. Оцінка та прогнозування якості природних вод. - К.: Ніка Центр. - 2001. - 196 с. 4. Шитиков В. К., Розенберг Г. С., Зинченко Т. Д. Количественная гидроэкология: методы системной идентификации. - Тольятти: ИЭВБ РАИ, 2003. -463 c. 